ФОРМУВАННЯ АКАДЕМІЧНОЇ КУЛЬТУРИ СТУДЕНТІВ

У ПРОЦЕСІ ЗДІЙСНЕННЯ ДОСЛІДНИЦЬКОЇ ДІЯЛЬНОСТІ

\title{
FORMATION OF STUDENTS' ACADEMIC CULTURE IN THE PROCESS OF RESEARCH ACTIVITY
}

УДК 378: 37.091

DOI https://doi.org/10.32843/2663-

$6085 / 2020 / 28.46$

\section{Фенцик О.М.,}

канд. пед. наук,

доцент кафедри педагогіки дошкільної, початкової освіти та освітнього менеджменту

Мукачівського державного університету
Статтю присвячено аналізу особливостей формування академічної культури студентів у процесі здійснення дослідницької діяльності. Увагу зосереджено на аналізі дослідницького навчання фрахівців з інфооммаційної, бібліотечної та архівної справи з урахуванням специфріки їхньої професійної діяльності. Встановлено, що цілі, завдання, методи, технологію організації дослідницького навчання можна ефрективніше реалізувати 3 використанням принципів соціокультурного підходу, згідно з яким відбувається фоормування академічної культури студентів. У процесі дослідження було встановлено, що академічна культура $\epsilon$ обов'язковим компонентом корпоративної культури університету, що базується на педагогічних цінностях, без якої не може існувати конкурентоспроможна освітня установа. Представлено цінності європейської академічної культури, задекларовані в Бухарестській декларації етичних цінностей і принципів вищої освіти в Європі, ключовими з яких $\epsilon$ чесність, довіра, прямота, повага, відповідальність і підзвітність. Академічну культуру проаналізовано з позиції системного підходу, що передбачає систему цінностей, норм, правил, зразків поведінки, способів діяльності, принципів спілкування, засновану на педагогічно адаптованому досвіді наукової пізнавальної діяльності.

До ссрери академічної культури зараховують академічну діяльність, академічні інститути, академічне письмо, академічну комунікацію, академічну мобільність викладачів i студентів, академічний менеджмент, підвищення кваліськації та академічного статусу. Серед ключових компетентностей дослідника - фрахівця з інфоормаційної, бібліотечної та архівної справи виокремлено володіння вмінням діалогового спілкування в процесі презентації матеріалів та результатів наукового дослідження у вигляді наукових статей, вмінням операційно обробляти наукові тексти різних жанрів наукового стилю, моделювати зв'язні наукові тексти із використанням новітніх інфрормаційно-комунікаційних технологій.

Ключові слова: академічна культура, дослідницька діяльність, цінності, формування.

The article is devoted to the analysis of features of formation of students' academic culture in the course of realization of research activity.
Attention is focused on the analysis of research training specialists in information, library and archival affairs, taking into account the specifics of their professional activities. It is established that the purposes, tasks, methods, technology of the organization of research training can be realized more effectively with use of principles of the sociocultural approach. Students' academic culture is formed by means of this approach.

The study found that academic culture is a mandatory component of the university's corporate culture, based on pedagogical values. There can be no competitive educational institution without these values. There are presented the values of European academic culture declared in the Bucharest Declaration of Ethical Values and Principles of Higher Education in Europe. The key of those values are honesty, trust, directness, respect, responsibility and accountability. "Academic culture" is analyzed from the standpoint of a systematic approach. This approach provides a system of values, norms, rules, patterns of behavior, methods of activity, principles of communication, based on pedagogically adapted experience of scientific cognitive activity.

The sphere of academic culture includes academic activities, academic institutes, academic writing, academic communication, academic mobility of teachers and students; academic management, advanced training and academic status. Among there were singled out the key competencies of the researcher - a specialist in information, library and archival affairs, the possession of the skills of dialogic communication in the process of presentation of materials and results of scientific research in the form of scientific articles; ability of operational processing of scientific texts of various genres of scientific style; modeling of coherent scientific texts using the topical information and communication technologies. The formation of students' academic culture will be more effective in the study of the discipline "Fundamentals of Scientific Research". Particular emphasis should be placed on the individual selection of tasks with a focus on their practiceoriented orientation and actualization of students independent work. In the process of research, the student poses a problem, puts forward a hypothesis and suggests possible solutions, tests the hypothesis, draws conclusions and generalizations.

Key words: academic culture, research activity, values, formation.
Постановка проблеми у загальному вигляді. Будь-яка діяльність визначається цінностями і зразками поведінки, складниками культури громадянського суспільства. Модернізація вітчизняних закладів вищої освіти впливає на академічну культуру, яка є показником якості та індикатором стану вищої освіти в Україні. Дослідницьке навчання $€$ індивідуальною освітньою траєкторією входження особистості студента до соціокультурного про- стору, особливо це стосується майбутніх фрахівців з інфрормаційної, бібліотечної та архівної справи.

Дослідницьке навчання зосереджує увагу на орормуванні в студентів потреби в реалізації пізнавальної активності, вмінь користуватися дослідницькими методами пізнання для розв'язання навчальних та життєвих завдань. Цей освітній результат називають особливим стилем життя, при якому пошукова активність займає одне з провідних місць [12]. 
3 позиції методології освіти, дослідницьке навчання зосереджено на процесі інкультурації студентів, залучення їх до основ академічної культури, яка $€$ невід'ємним складником профресійної компетентності майбутніх фрахівців 3 інформаційної, бібліотечної та архівної справи.

Поняття «академічна культура» українські вчені [13] пов'язують із культурою навчання в університеті, цінностями, традиціями, нормами, правилами проведення наукових досліджень; науковою мовною культурою, культурою високої духовності і моралі, культурою спілкування наукових наставників та студентів, культурою наукової праці і соціальної, моральної відповідальності за результати дослідження, культурою толерантності і педагогічного оптимізму, що фрормується в культурно-освітньому просторі закладів вищої освіти.

Студенти, викладачі й адміністрація закладів вищої освіти визнають, підтримують та сповідують цінності академічної культури, виходячи з того, що вища школа не може розвиватися, ігноруючи ці цінності. Цінності академічної культури мають пронизувати освітньо-професійні програми підготовки майбутніх фрахівців 3 інформаційної, бібліотечної та архівної справи, в основу яких покладено ідею випереджувального підходу до підготовки компетентних фрахівців-дослідників, які розв'язуватимуть комплексні проблеми професійної та дослідницької діяльності в бібліотеці.

Аналіз останніх досліджень і публікацій. Дослідженню академічної культури та окремих її елементів приділяли увагу зарубіжні (Д. Джонс, Л. Тревіно, К. Батерфілд, Т. Бечер, Н. Горденко, О. Єрохіна, П. Мендоза та ін.) і вітчизняні вчені (М. Вовк, Т. Добко, О. Кравченко, І. Пак, О. Семеног, Г. Хоружий та ін.).

Виділення не вирішених раніше частин загальної проблеми. Незважаючи на вагомі наукові результати досліджень, поза увагою дослідників залишилася проблема аналізу академічної культури студентів у процесі здійснення дослідницької діяльності.

Мета статті - проаналізувати теоретичні аспекти та узагальнити особливості формування академічної культури студентів у процесі здійснення дослідницької діяльності.

Виклад основного матеріалу. Дослідницька діяльність спрямована на активізацію особистісної позиції студента в освітньому процесі на основі засвоєння суб'єктивно нових знань, фрормування дослідницьких умінь як універсального способу освоєння дійсності, розвиток здатності до дослідницького типу мислення. У процесі спеціально організованого дослідження студент опиняється в ситуації, коли він сам досліджує сутність понять, явищ і аналізує підходи до розв'язання проблем.

Підтримуємо О. Карпова в тому, що дослідницьке навчання зосереджено на розробці інно- ваційних освітніх методів і створенні спеціалізованих навчальних закладів, оскільки воно дає змогу вийти за межі освітніх традицій [7]. У контексті нашого дослідження цікавим $€$ тлумачення «дослідницького навчання» О. Савенкова, який представляє його як «особливу модель навчання, реалізація якої спрямована на фрормування у студентів дослідницької позиції щодо себе і світу. Автор наголошує, що дослідницька діяльність не має бути регламентованою будь-якими зовнішніми установками» [12, с. 31$]$.

Враховуючи специфіку профресійної діяльності срахівців з інсормаційної, бібліотечної та архівної справи, вважаємо, що цілі, завдання, методи та технологія організації дослідницького навчання можуть бути успішніше реалізовані на основі принципів соціокультурного підходу, згідно з яким сорормована академічна культура передбачає культуру високої духовності і моралі, культуру особливої поведінки і спілкування людей, які професійно покликані забезпечувати трансляцію культурних цінностей.

3 позиції культурологічного підходу, «освіта $\epsilon$ соціокультурною системою, яка забезпечує культурне наслідування (трансляцію культурних норм, цінностей, ідей), розвиток людської індивідуальності, підготовку людини до успішного існування в соціумі, власній культурі, полікультурному середовищі; як процес прилучення людини до культури і водночас як результат інтеріоризації культури, включення її у світ людської суб'єктності» [14, с. 13].

Метою дослідницького навчання $€$ осягнення студентами цінностей, норм і традицій академічної культури. В академічному тлумачному словнику української мови термін «академічний» трактується як: 1) навчальний (стосовно вищих навчальних закладів); 2) суто теоретичний, абстрактний; який не має практичного значення, відірваний від життя; 3) який додержується встановлених традицій у мистецтві [15]. Підтримуємо М. Кастельса в тому, що культура $є$ набором цінностей і переконань, що визначають поведінку людини [8].

Феномен «академічна культура» знаходиться в полі зору багатьох учених, які по-різному розуміють це поняття. Представимо найбільш поширені погляди на трактування сутності цього терміна (табл. 1).

Сучасне розуміння цінностей академічної культури було сорормульоване в Бухарестській декларації етичних цінностей і принципів вищої освіти в Європі, де наголошено, що ключовими цінностями сумлінної академічної спільноти є чесність, довіра, прямота, повага, відповідальність і підзвітність. До основних цінностей європейської академічної культури зараховують:

- інтелектуальну свободу та соціальну відповідальність;

- моральну відповідальність самостійних дослідників і вчених не тільки за процес дослі- 
Наукові підходи до трактування поняття «академічна культура»

\begin{tabular}{|l|c|}
\hline \multicolumn{1}{|c|}{ Зміст поняття «академічна культура» } & Автор \\
\hline $\begin{array}{l}\text { Обов'язковий компонент корпоративної культури університету, що базується на педагогічних } \\
\text { цінностях, без якої не може існувати конкурентоспроможна освітня установа [1] }\end{array}$ & О. Бєляєв \\
\hline $\begin{array}{l}\text { Оволодіння різними видами та способами навчально-пізнавальної та навчально-дослідниць- } \\
\text { кої діяльності, готовність до переходу від теоретичного до практичного навчання, вміння раці- } \\
\text { онального читання, підготовки до занять, різних форм атестації [3] }\end{array}$ & Н. Горденко \\
\hline $\begin{array}{l}\text { Важлива передумова есективного управління сучасним університетом; спільнота студентів і } \\
\text { викладачів, об'єднаних спільним прагненням до знань і розумінням світу, що виходять далеко } \\
\text { за межі конорормізму, з інтересами будь-яких суспільних чи політичних груп [4, с. 94] }\end{array}$ & Т. Добко \\
\hline $\begin{array}{l}\text { Виявляє ті особливості наявних освітньо-наукових систем, які дають змогу сприймати їх як } \\
\text { специфічне культурне явище [9, с. 439] }\end{array}$ & О. Кравченко \\
\hline $\begin{array}{l}\text { Інтелектуально-етична система цінностей, мотивацій, переконань та сприйняттів, що визна- } \\
\text { чають просресійну діяльність в освіті та науці [11] }\end{array}$ & В. Ромакін \\
\hline $\begin{array}{l}\text { Сукупність способів і методів діяльності університетської спільноти, її системна інтегрована } \\
\text { якість, що відбиває досягнутий рівень розвитку [16] }\end{array}$ & Г. Хоружий \\
\hline
\end{tabular}

джень (вибір теми, методи і сумлінність), але і за їхні результати;

- прагнення окремих наукових співтовариств до співпраці у світовому масштабі;

- право вчених на свободу вираження поглядів про наукові та етичні аспекти дослідних проєктів і їхні результати; усуватися від участі в проєктах, які суперечать їхнім переконанням і совісті;

- самоцінність інтелектуальної роботи незалежно від того, коли буде отримано результат [2].

Підтримуємо І. Пак у тому, що «академічна культура поєднує науку, культуру та знання, механізми їі виникнення визначаються як історично сформованою, так і сучасною соціокультурною ситуацією на певному етапі розвитку суспільства» [10, с. 23]. Академічну культуру вважають культурою вищої освіти, яка зосереджує увагу не тільки на навчанні, викладанні та методичному забезпеченні цих процесів, а й усьому комплексі соціокультурних практик, пов'язаних із функціонуванням закладів вищої освіти.

Цікавим для нашого дослідження є трактування «академічної культури» О. Єрохіної, яка розуміє її як систему цінностей, норм, правил, зразків поведінки, способів діяльності, принципів спілкування, засновану на педагогічно адаптованому досвіді наукової пізнавальної діяльності [5, с. 64]. Когнітивний рівень академічної культури передбачає наявність знань про способи пізнавальної діяльності в ситуації дослідження. При цьому академічна культура закріплює традиції і норми проведення наукового дослідження і фріксації його результатів (виявлення проблеми, висування гіпотези, проведення дослідження, аналіз отриманих даних, підтвердження або спростування гіпотези). Операційний рівень академічної культури поєднує комплекс умінь, необхідних для взаємодії у процесі дослідження, вербалізації цього процесу і результату. Йдеться про вміння усвідомлювати необхідність і важливість проведення дослідження, створювати текст під час проведення дослідження, підбирати докази на основі наукового опису проведеного дослідження та отриманого результату, аналізувати підібрані аргументи, вербалізувати отримані результати. Ціннісний рівень академічної культури визначає зміст і мету дослідницької діяльності.

Погоджуємося з І. Забіякою, який до сорери академічної культури зараховує такі складники:

- академічна діяльність - навчальна (читання лекцій, організація самостійної роботи студентів, керівництво науковою роботою студентів, методична робота викладачів) та наукова (теоретичні дослідження, архівна робота, лабораторні досліди та експерименти, опитування, польові дослідження, експедиції тощо);

- академічні інститути (університет, наукове товариство, бібліотеки й архіви, фонди, лабораторії, віртуальні науково-освітні портали тощо);

- академічне письмо (написання публіцистичних, популярних, наукових, методичних, кваліфікаційних текстів у формі статті, есе, доповіді на конференції, кваліфікаційної випускової роботи, монограсрії, наукового перекладу тощо);

- академічна інорорматика, що передбачає сорормованість бібліографрічної компетентності, використання каталогів, баз даних, індексів наукового цитування, віртуальних джерел і бібліотек тощо;

- академічна комунікація - конференційна діяльність, академічна риторика, професійна етика автора, викладача, академічне право, науково-кваліфрікаційні заходи (захисти кваліфікаційних випускових робіт, презентації книг тощо);

- академічна мобільність викладачів і студентів;

- академічний менеджмент - управління та організація академічних інститутів та проєктів, академічний фандрайзинг, написання грантових проєктів;

- підвищення кваліфрікації та академічного статусу (нефрормальна та інфрормальна освіта) [6, с. 148].

На основі наукових доробок О. Семеног i М. Вовк [13] ми виокремили загальні компетентності дослідника - фрахівця з інфрормаційної, біблі- 
отечної та архівної справи, серед яких основними $€$ вміння діалогового спілкування у процесі презентації матеріалів та результатів наукового дослідження у вигляді наукових статей, доповідей, мультимедій, вміння операційно обробляти наукові тексти різних жанрів наукового стилю (реферування, анотування, конспектування тощо), моделювати зв'язні наукові тексти (створювати глосарії ключових термінів; готувати наукові статті, тези, доповіді, повідомлення, виступи, наукові звіти, посібники) з використанням новітніх інформаційно-комунікаційних технологій.

Формування академічної культури студентів можливе за такої організації їхньої пізнавальної діяльності, за якої навчальний матеріал стає предметом активних розумових і практичних дій кожного 3 них. Дисципліна «Основи наукових досліджень» заснована на застосуванні інноваційних освітніх технологій із використанням інтерактивних методів навчання. Важливо акцентувати на індивідуальному підборі завдань, зважаючи на їх практико орієнтовану спрямованість та актуалізацію самостійної роботи студентів. Серед ключових умінь академічної культури майбутніх фрахівців 3 інфрормаційної, бібліотечної та архівної справи особливу увагу необхідно зосереджувати на вмінні працювати з періодичними виданнями, логічно мислити, правильно оцінювати фрактичну інсрормацію, володіти правилами наукового викладу матеріалу тощо.

Слід зазначити, що у процесі дослідницької діяльності майбутні фахівці з інформаційної, бібліотечної та архівної справи розв'язують дослідницькі, творчі завдання, що націлені на послідовну поетапність дій: постановка проблеми, вивчення теоретичного матеріалу, присвяченого вибраній проблемі, підбір методів дослідження, аналіз та узагальнення теоретичного матеріалу, фрормулювання висновків.

Загалом у процесі дослідницького навчання студент ставить перед собою проблему, яку необхідно вирішити, висуває гіпотезу і пропонує можливі варіанти її розв'язання, перевіряє гіпотезу і на основі отриманих даних робить висновки та узагальнення.

Висновки. Отже, дослідницька діяльність має стати невід'ємною частиною самостійної роботи студентів, ключовою ланкою в організації навчального процесу. Вона сприяє становленню їх соціально-психологічної зрілості, підвищенню якості підготовки фрахівців і розвитку наукового потенціалу вищої школи. Формування академічної культури студентів є доказом високої якості їхньої самостійної роботи, сприяє підвищенню їхньої пізнавальної та творчої активності.

\section{БІБЛІОГРАФІЧНИЙ СПИСОК:}

1. Беляев А. Корпоративная культура университета: от теории к практике. Высшее образование в России. 2007. № 11. С. 62-67.
2. Бухарестская декларация этических ценностей и принципов высшего образования в Европе, 10 августа 2005 г. ЮНЕСКО-СЕПЕС. URL: http://www.almamater.md/articles/879/ru.html

3. Горденко Н.В. Формирование академических компетенций у студентов вуза : авторефр. дис. ... канд. пед. наук : 13.00.08 / Ставропольский государственный университет. Ставрополь, 2006. $20 \mathrm{c.}$

4. Добко Т. Академічна культура, як необхідна передумова ефективного управління сучасним університетом в умовах автономії. Університетська автономія. Київ : Дух і Літера, 2008. С. 93-102.

5. Ерохина Е.Л. Академическая культура учащегося-исследователя в условиях внедрения ФГОС. Академический вестник Института педагогического образования и образования взрослых. Человек и образование. 2014. № 2 (39) С. 64-67.

6. Забіяка І.М. Теоретичні аспекти формування академічної культури студентів в умовах сучасного університету. Педагогіка формування творчої особистості у вищій і загальноосвітній школах. 2016. Вип. 51 (104). С. 144-150.

7. Карпов О.А. Как организовать исследовательское обучение школьников. Народное образование. 2011. № 2. C. 36-42.

8. Кастельс М. Галактика Интернет: Размышления об Интернете, бизнесе и обществе. Екатеринбург : У-Фактория, 2004.

9. Кравченко О.В. Культурологія у вимірах традицій академічної культури. Культура України. 2013. Вип. 42. С. 439-450.

10. Пак І.В. Академічна культура українського студентства: фрактори фрормування та особливості прояву : дис. ... канд. соціологічних наук : 22.00.04. Харків, 2019. 251 с.

11. Ромакін В.В. Мотивації, переконання та поведінка українських і американських студентів бакалаврату щодо норм академічної культури. Наукові праці Чорноморського державного університету імені Петра Могили. Педагогіка. 2010. Вип. 123. Т. 136. C. $34-41$.

12. Савенков А.И. Исследовательское обучение и проектирование в современном образовании. Исследовательская работа школьников. 2004. № 1. C. 22-31.

13. Семеног О., Вовк М. Академічна культура дослідника в освітньо-культурному просторі університету : монографрія. Суми : Вид-во СумДПУ імені А.С. Макаренка, 2016. 284 с.

14. Сисоєва С. Розвиток освіти в умовах полікультурного глобалізованого світу. Проблеми полікультурності у неперервній професійній освіті : наук. видання / за ред. чл.-кор. НАПН України К.В. Балабанова, С.О. Сисоєвої, проф. І.В. Соколової. МОНМС, Маріупольський держ. ун-т. Маріуполь : Вид-во Ноулідж, 2011.

15. Словник української мови. Академічний тлумачний словник (1970-1980). URL: http://sum.in.ua/p/1/25/2

16. Хоружий Г.Ф. Академічна культура: цінності та принципи вищої освіти. Тернопіль : Навчальна книга Богдан, 2012. 320 с. 